\title{
Micro Retail Enterprise in China: Healthier and More Mature*
}

\author{
Walter Huber \\ Muskingum University, Ohio, USA \\ Yuqin Luan \\ North China Institute of Science and Technology, Hebei Province, China \\ Yuning Ji, Xinyue Xu, Ziheng Xu \\ Muskingum University, Ohio, USA
}

\begin{abstract}
Micro Retail Enterprises (MREs) in China play an important but underappreciated role in China's economy. The authors built on the published results of a survey of MREs conducted the previous year. The authors surveyed 2,174 MREs in four cities in China in an effort to determine their access to both formal and informal sources of credit, use of credit cards and mobile payments (m-payments), entrepreneurship and business strategy. While some trends remain the same, at least two significant findings emerge: insights on access to loans and the fast rise of m-payments. While less than $8 \%$ of MREs have been successful in securing a traditional business loan from one of the state-run banks, approximately two-thirds of MREs have found ways to access credit, most commonly with loans from family and friends. Implications of this are explored and it is argued that better access to business loans for MREs would help this sector mature. On the positive side, m-payments have exploded in popularity over a very short period of time. Almost $90 \%$ of MREs accept at least one form of m-payment and owners report the importance of them for business growth. It is argued that m-payments may represent a form of leapfrogging technology which will spur growth in this sector.
\end{abstract}

Keywords: Micro Retail Enterprise (MRE), mobile payment (m-payment), Chinese entrepreneur

Small and Medium Enterprises (SMEs) play an outsized role in China's economy, contributing 59\% of GDP in recent years (Liu, 2008). SMEs in China are making an increasingly important positive contribution to the economy, unemployment, and income at a time larger businesses contribution is declining (Chan \& Lin, 2013). Both government policy and most research on this sector focus the vast majority of resources on the larger players in this sector. The government has adopted several supportive measures to support SMEs in general. There have been excellent studies of how the sector as a whole has dealt with the new normal in China

\footnotetext{
* The authors would like to acknowledge the generous contribution of Muskingum University to this research in the form of a 2017 Summer Muskie Fellow.

Corresponding author: Walter Huber, Ph.D., Professor, Department of Political Science and Director of the Center for Regional Planning and Development, Muskingum University, Ohio, USA; research fields: education policy, economic policy, environmental policy, political economy, comparative public policy.

Yuqin Luan, M.A., Dean, College of Foreign Languages, North China Institute of Science and Technology, Hebei Province, China; research fields: economic policy, foreign language, education policy, teaching pedagogy.

Yuning Ji, B.A. candidate, Accounting, Muskingum University, Ohio, USA; research fields: economic policy, accounting.

Xinyue Xu, B.A. candidate, Business Management, Muskingum University, Ohio, USA; research fields: economic policy, management.

Ziheng Xu, B.A. candidate, Accounting, Muskingum University, Ohio, USA; research fields: economic policy, accounting.
} 
of a still fast but slowing economy. The focus of the laws and the research however largely ignores Micro Retail Enterprises (MREs) which take the form of street venders, souvenir stands, specialty retail stores, convenience stores, restaurants, service providers, and venders of household goods. This is important since these businesses are both ubiquitous and an important safety valve for new opportunities when State Owned Enterprises (SOEs) downsize their workforce.

These independent businesses have been shown to represent an important part of China's economy and are largely ignored (Huber et al., 2017). These MREs are defined as private owner-operated non-franchise retail businesses with a single location employing fewer than five individuals outside of the members of the owner's family. The authors conducted some preliminary work on how these businesses are coping with slower growth and what government policies will help them thrive (Huber et al., 2017) and this research builds on those findings by surveying 2,174 MREs in different cities in China. The authors asked many of the same questions a second time along with new questions developed from the findings of the previous article (Huber et al., 2017).

Questions about business strategies, changes in profits, acceptance of non-cash payments, and preferred government policies remained. However, there were several findings the authors wanted to explore. Last year, $41.6 \%$ of respondents reported they were able to secure a bank loan to support their business. This runs counter to conventional wisdom on Chinese banks' willingness to lend to MREs. The authors speculated that many of the loans were not in fact business loans from state-run banks but repurposed family loans, mortgages, private bank loans, or the like. The authors broke the question down in this survey to find out exactly how MREs are funding their business operation and expansion. The literature maintains that SMEs in China face large and persistent financing challenges (Shi, 2007). Most banks in China do not want to issue loans to SMEs since they are seen riskier clients than large companies (Dudovsky, 2012). MREs should face even greater challenges than most in getting credit. Finding out how they are in fact borrowing capital is a valuable insight.

The second area the authors expanded questions on revolved around interesting findings for non-cash payment options. The previous study found $59.2 \%$ of MREs accept bank cards. This bodes well for MREs since Chinese consumers (particularly younger consumers) have begun to spend more using credit cards which can provide "instant gratification" (Wang, 2009). Since the authors conducted the last survey, WeChat Pay and Alipay have exploded in popularity. WeChat has become the most influential mobile social networking application in China. Over 200 million users registered a WeChat payment (equivalent to Alipay or Apple Pay) account using their credit cards and 58.1\% of them had used WeChat as a form of payment (Chen, 2017). WeChat Pay and Alipay are much easier to accept than credit cards and the authors added in questions on whether MREs accept these forms of payment, reasons why if they do not accept it, and perceived benefits of those who have adopted this form of payment.

\section{Access to Credit}

China's government has, for more than a decade, acknowledged the problem SMEs have in obtaining bank loans and worked to address this issue. SME financing was explicitly added to the national development agenda, which in 2003, resulted in the "SMEs Promotion Law" (Chong, Lu, \& Ongena, 2013). It is generally assumed that the paperwork required to get a bank loan serves as an impediment. To cite one example, the Bank of China requires the following documentation for all business loans: qualification documents (ID cards, business licenses, etc.); financial statements of the operation (or operating income certificates); tax receipts; official certification of stable income and employment; and additional documentation as requested (Bank of China, n.d.). 
Limited access to traditional business loans has been shown to lead to SMEs being more likely to use less formal sources of credit primarily because acquiring capital and dealing with financial institutions are particularly difficult for small businesses (Chan \& Lin, 2013). Eighty-nine percent of the entrepreneurs surveyed by Chan and Lin indicated that they had funded their enterprises without traditional bank loans. Other researchers have also found that the family played a central role in supporting entrepreneurial-led SME development. The household and extended family tend to provide primary sources of start-up capital. Another study found that $40 \%$ of SMEs surveyed had at least one family investor; $19.6 \%$ had two (Pistrui, Huang, Oksoy, Jing, \& Welsch, 2001).

There are many reasons for this being common in SMEs in China. Common explanations include a lack of interest on the part of banks to serve SMEs, immature credit markets, information asymmetry, skewed credit allocation that favors SOEs over private enterprises, and the slow development of the venture capital market (Liu \& Huang, 2016). The problems faced by SMEs in general are likely much more acute for MREs. Finding out how this part of the SME sector is accessing credit will help paint a clearer picture of how much reforms to the banking sector have improved lending to different types of businesses.

\section{The Growth of Non-Cash Payments}

Payment by credit card and mobile platforms has grown in popularity in China in recent years. Mobile payment (m-payment) growth has been particularly fast. The transaction volume of m-payment in China exceeded RMB 5,992 billion (or USD 966 billion) in 2014, with an increase of 391.3\% over that of 2013 (Wu, Liu, \& Huang, 2017). Credit cards can be more expensive to accept than cash or checks for businesses, but some customers prefer to only use credit cards. Refusing to accept credit cards can mean sacrificing repeat sales. Additionally, business-to-business (B2B) shops can pick up new customers by being credit card friendly, and are well positioned as a first alternative when a competitor is out of inventory (Hammermaster, 2010). One survey found that about two-thirds (68\%) believe that paying by credit card actually encourages people to spend beyond their budget (Worthington, Thompson, \& Stewart, 2011). Young consumers across China have begun to spend more using credit cards, providing "instant gratification" (Wang, 2009). In the authors' article last year, they found that 59.2\% of MREs surveyed accept bank cards (Huber et al., 2017).

WeChat Pay and Alipay have emerged as the biggest m-payment platforms in China. A recent study found that 200 million users registered WeChat Pay account (equivalent to Alipay or Apple Pay) using their credit cards and $58.1 \%$ of them had made a payment with WeChat Pay (Chen, 2017). The average daily trading volume of Alipay is 10.6 billion yuan (Liu, 2015). As McKay (2010) argued, Chinese millennials generate an estimated $\$ 54.3$ billion RMB opportunity for brands. This can partially be attributed to millennial Chinese preferring a digital lifestyle (Russell, 2016) and frequently using WeChat Pay for various aspects of life, including calling taxis, purchasing public transportation and entertainment tickets, booking restaurants, making public utility payments, doing exercises, and making donations (Tencent Technology, 2016). M-payments have the potential to transform the business model MREs adopt.

\section{Research Design}

The authors conducted a survey of 2,174 MREs in four cities in China. A 12-question instrument was developed and translated into Mandarin. Surveys were administered in person during a five-week period in June and July of 2017. Surveys were administered in the cities of Xi' an, Lanzhou, Beijing, and Chongqing. The 
cities were chosen to provide geographic and economic diversity. Xi' an and Lanzhou are located in northwest China, Beijing is located in north China, and Chongqing is located in the south. Beijing is the capital of China, Chongqing is a provincial-level city (city given the same status as a province), $\mathrm{Xi}$ 'an is a first-tier city in Shaanxi Province, and Lanzhou is a second-tier city in Gansu Province.

The first part of the survey had two questions. MREs were classified into one of eight types of business: convenience store, souvenir (tourism), specialty retail (domestic market), restaurant, vender, service, household goods store, or specialty food. Second, MREs were asked whether sales and expenses were up, down, or stagnant compared to a year ago. The authors broke this into a question on whether sales were increasing, decreasing, or unchanged compared to last year and whether costs were increasing, decreasing, or unchanged compared to last year.

The second part of the survey focused on bank loans, credit card acceptance, and m-payment acceptance. Respondents were asked whether they had ever taken out a bank loan from one of the state-run banks to support their business, whether they ever took out any other type of loan and used the funds to support their business (apartment mortgage, local bank loan, family/friends, private commercial bank loan, or type of bank not listed), whether they accepted credit cards, reasons why if they did not, whether they accepted m-payments from customers, reasons why if they did not, and what they perceive the advantages are of accepting credit cards and m-payments from customers. This section explored MREs' access to credit, how well they were connected to the digital economy, and potential roadblocks they face.

The final section of the survey asked respondents what was the primary reason they decided to open their business (more money from self-employment, desire to become a boss, greater independence and freedom from an entrepreneurial lifestyle, or no better choice for a job; which business strategies they used in the past six months; and whether they expected business to improve, stay the same, or decline over the next 12 months). These questions sought to better understand whether MRE owners are intentional entrepreneurs, how MREs are coping with a changing economy, and their view about the future.

\section{Results}

2,174 MREs were surveyed (264 convenience stores, 265 souvenir, 278 specialty retail, 327 restaurants, 246 venders, 334 service providers, 263 household goods stores, and 197 specialty food stores). The 11.9\% reported declining sales, $38.7 \%$ reported rising sales, and $49.4 \%$ reported flat sales. Costs were lower than the previous year for $6.5 \%$, higher for $47.5 \%$, and flat for $46 \%$. A chi-square test revealed that there was a significant relationship between the variables [chi square $(4, \mathrm{~N}=2,087)=119.61, p=0.000$ ]. MREs with lower costs reported lower sales and MREs with higher costs reported higher sales. This is suggestive that while cost may be rising for some MREs, it is being at least partially set off by rising sales.

The survey conducted last year found that $41.6 \%$ of respondents claimed they had a current loan from a bank to support their business. This number seemed quite high and ran counter to conventional wisdom. In an effort to explore what was happening, the authors separated the question into two questions. First, the authors asked "Have you ever taken out a business loan from one of the state-run banks (The Bank of China, China Construction Bank, Agricultural Construction Bank, Bank of Communications, or Industrial and Commercial Bank of China) to support your business?". They then asked, "Have you ever taken any other loan?" (check all that apply) with the following options: apartment mortgage, local bank loan, family or friends, private commercial bank loan, or type of bank not listed. The first question was meant to limit "yes" responses to 
MREs able to secure a traditional business loan from a major bank. The second question allows an exploration of less formal forms of financing MREs might resort to. Only 7.9\% of MREs reported being able to secure a business loan from one of the state-run banks. Of those able to secure this type of business financing, $31.6 \%$ were restaurants, 21.6 were service providers, $12.9 \%$ sold household goods, and $10.5 \%$ were specialty food venders. Of those who did not have a loan from one of the state-run banks, $17.7 \%$ expressed a desire for one but were unable to secure financing. The second question on loans found that the most popular form of financing was family and friends (52.9\%) with no other type of loan approaching $20 \%$ of total respondents. The $66.5 \%$ of respondents reported having taken out at least one type of loan.

The $34.8 \%$ of MREs accept bank cards and of those who do not, $12.3 \%$ were considering accepting them in the future. Of the $65.2 \%$ who do not accept bank cards, $31.1 \%$ felt the service fee was too high, $43.2 \%$ lacked easy access to the machine, $37.9 \%$ cited personal reasons, and $13.9 \%$ reported they did not know how to gain access. These numbers are actually down from last year which is likely explained by the astonishing rise in the acceptance of m-payment options. The authors asked MREs whether they accepted Alipay or WeChat Pay from customers. A mere $10.1 \%$ of MREs do not accept either m-payment platform and of those not currently accepting at least one m-payment option, over half (56.1\%) are considering doing so in the future.

Of those who accept Alipay, WeChat Pay, or both, $87.4 \%$ believe it increases business either a little (64.7\%) or a lot (22.7\%). The $29.8 \%$ of MREs who accept m-payments use them to develop their business. Of those who do not currently accept m-payments from customers, $37 \%$ report personal reasons, $12.3 \%$ say they do not have a smart phone, $30.9 \%$ say they do not know how to set it up, $26.1 \%$ say it is because fees are too high, but only $8.7 \%$ say it is because their customers do not want to pay via m-payment. When asked what they saw as the primary advantage of accepting credit cards and/or m-payments, $41.1 \%$ cited customer happiness, $29.8 \%$ cited increased sales, and $19.8 \%$ believed it would result in new customers. The $2.1 \%$ cited another reason (saves time when conducting transactions, increased security, no need to change large bills, and easier to fill in required business tax forms), and $7.3 \%$ did not see any advantage. Those who accept m-payments are slightly less likely to believe business will decline over the next 12 months than would be expected but those who do not accept m-payments are almost three times more likely to expect business to decline than would be expected: 33 actual versus 11.1 expected [chi square $(2, \mathrm{~N}=2,161)=50.546, p=0.000$ ].

In an effort to understand why these individuals started their business, the authors asked what their primary reason was. The $30.6 \%$ said it was a desire to become their own boss, $28.6 \%$ cited a belief they would earn more money from self-employment, $26.5 \%$ cited the greater independence and freedom an entrepreneurial lifestyle provided, and $14.3 \%$ said they had no better choice for a job. Of those who said they had no better choice for a job, they did not flock to a particular sector. The smallest percentages reported (9.6\%) opened either specialty retail or souvenir stores catering to tourists. The largest percentage of those who felt they had no better choice $(16.6 \%)$ opened service stores such as barbers or laundry services. The authors did find a difference for those who perceived no better choice than opening a business in terms of accepting m-payments. This group was more than two times less likely to accept m-payments than those who opened their business for other reasons: 53 actual versus 26.5 expected [chi square $(1, \mathrm{~N}=1,887)=34.227, p=0.000$ ].

Looking at different business strategies MREs might adopt, the authors found that in the six months prior to the survey being administered, $38.8 \%$ increased their hours of operation, $18.2 \%$ lowered prices, $5.7 \%$ reduced staff, $18.9 \%$ expanded their business, $27.8 \%$ advertised, and $21.8 \%$ ran a promotion. Using chi-square, the authors analyzed the effect of the type of business, whether they accepted credit cards, whether they 
accepted m-payments, and their primary motive for starting their business in terms of any influence it might have on which business strategy they would employ. For "type of business" and for "accepting credit cards", there was no difference in any of the six business strategies. All were equally likely to adopt each strategy. For m-payments, two differences were noted. MREs who did not accept m-payments were less likely to have advertised [chi square $(4, \mathrm{~N}=2,158)=34.92, p=0.000$ ]. For those who were not currently accepting m-payments but were considering it, they were less likely to have expanded their business in the past six months than those accepting $\mathrm{m}$-payments [chi square $(4, \mathrm{~N}=2,161)=13.177, p=0.010]$.

The final question the authors asked was the general outlook the MRE had about their business over the next 12 months. Generally, respondents were optimistic with 39.3\% expecting business to improve, 55.6\% expecting it to remain the same, and only $5.2 \%$ expecting business to get worse. However, of those expecting business to get worse, they were different than their peers in several ways. They were more likely to report sales had dropped from the previous year (39.4\% versus $11.9 \%$ for the entire sample), more likely to not accept m-payments ( $9.9 \%$ versus $4.6 \%$ for "neither" and $19.8 \%$ versus $5.5 \%$ for "no, but considering"), more likely to cite no better option as the reason they opened their business (37.2\% versus $14.3 \%)$, less likely to have adopted expansive business strategies, and more likely to have adopted defensive business strategies.

\section{Discussion}

While much is written about China's economy in general, relatively little is known about MREs in China. These businesses are an important part of the business sector and entrepreneurship has the ability to relieve pressure on the economy when SOEs and other larger corporations lay off workers. As China's economy continues to mature and shift towards services and domestic markets, this sector will continue to grow both in absolute size and in significance.

While only $7.9 \%$ of MREs had traditional business loans from a major bank, over half of all respondents have received financing through less formal means such as a loan from a family member. This is significant for several reasons. First, while it is correct to say that small companies in China face significant barriers in securing a traditional business loan to support their business, it does not take the full picture of what is occurring into account. Approximately two-thirds of all MREs need financing and over half turn to an informal network of family and friends for support. Official tallies of bank loans do not take this into account so access to credit for MREs is actually larger than it might first appear. Second, entrepreneurs who do not have access to a network of family and friends capable of standing in place of traditional banks will likely suffer disproportionately and either be unable to open a MRE or find themselves much more likely to be undercapitalized. This is an interesting finding that deserves additional study in the future to try and gauge the extent this is occurring and the implications for MREs and the broader economy.

The number of MREs accepting bank cards dropped from last year. This would be surprising if not for the overwhelming number of MREs now accepting at least one form of m-payment. Although m-payment platforms are relatively new (Alipay launched in 2009 and WeChat Pay launched in 2013), they have exploded in popularity, especially offline (Xiao, 2017). Retailers can accept either m-payment with a printed QR Code that customers can scan with their smartphone. The authors found $89.9 \%$ of MREs currently accepting m-payments from customers. This development has led to increases in business revenue $(87.4 \%$ of MREs report business is helped by m-payment although only $29.8 \%$ cite increased sales as the primary benefit). Interestingly, $41.1 \%$ of MREs cite customer happiness as the primary reason they accept m-payments. 
Historically, cell phones have been used as the primary example of leapfrogging technology. It has long been accepted that leapfrogging technology allows countries to rapidly catch up to and, in some cases, surpass their economic rivals by skipping development steps. Critics of this idea argue that cell phones are unique and that there are few other examples of leapfrogging technology since you generally need older technologies to take full advantage of newer innovations (The Economist, 2008). M-payment technology may be the replacement example for cell phones that is used when leapfrogging technology is discussed. Smart phones in China (the necessary older technology) are increasingly common. It is estimated that over 663 million people in China had smart phones in 2017 and it is expected that by 2022, over 816 million people in China will have a smart phone (Statista, n.d.). The underlying technology is already diffused across China. M-payments are more secure than credit cards and can be used by anyone with a smartphone. They speed transaction time, reduce the need to change large bills, make it harder for employees to steal, encourage spending, and put MREs on a more equal footing with larger retailers. The rise of m-payments at MREs is likely one of the more important but overlooked developments in China's retail sector. This is an important development that will make it easier for China's transition to a more developed economy that focuses more on services and the domestic market and should be an important factor in allowing MREs to continue to expand. Little has been written on this as of this date but hopefully more studies will be conducted to explore how m-payments are changing MREs.

\section{Conclusions}

While MREs have limited success in securing traditional business loans from national banks, they are able to finance with less formal sources of credit (most commonly with loans from family and friends). M-payments have dramatically risen in popularity with approximately $90 \%$ of all MREs accepting at least one form of m-payment. Both of these findings are interesting and point to subtleties in this sector of the economy not previously known. Future business growth depends in part on access to credit. While the majority of MREs have found access to some forms of credit, fewer than $8 \%$ have access to a traditional business loan. It is unclear how much business expansion is curtailed by this problem and more work needs to be done to answer that question. Recent government policy has seen some moves to ease access to bank loans for smaller firms and more efforts of this type will yield positive results. There is a clear demand for credit and as China continues to rebalance its economy, increasing assess to credit for MREs will play a role in easing this transition.

On the positive side, m-payments may well represent the newest example of leapfrogging technology. If so, that speaks well for the future of retail in China generally and for the growth prospects for MREs specifically. The fact that those who accept m-payments are more optimistic about future growth is a positive sign in this direction. A promising agenda for future research would explore how MREs cope with limited access to credit and what opportunity costs this imposes and further look at the importance of m-payments for MREs moving forward. So far, the Chinese government has helped regulate m-payments to improve faith in them but has not slowed their rise. It has been encouraging that the approach of the government has been helpful in the incredibly fast diffusion of this potential leapfrogging technology.

\section{References}

Bank of China. (n.d.). Personal investment business loans requirments. Retrieved from http://www.boc.cn/pbservice/pb2/200806/ t20080625_719.html

Chan, S. H., \& Lin, J. J. (2013). Financing of micro and small enterprises in China: An exploratory study. Strategic Change, $22(7-8), 431-446$. 
Chen, Y.-R. R. (2017). Perceived values of branded moblie media, consumer engagement, business-consumer relationship quality and purchase intention: A study of WeChat in China. Public Relations Review, 43(5), 945-954.

Chong, T., Lu, L., \& Ongena, S. (2013). Does banking competition alleviate or worsen credit constraints faced by small- and medium-sized enterprises? Evidence from China. Journal of Banking \& Finance, 37(9), 3412-3424.

Dudovsky, J. (2012). SMEs in China: Overview. Retrieved from https://research-methodology.net/small-and-medium-enterprises -in-china-overview/

Gan, C. E., Cohen, D. A., Hu, B., Tran, M. C., Dong, W., \& Wang, A. (2016). The relationship between credit card attributes and the demographic characteristics of card users in China. International Journal of Bank Marketing, 34(7), 966-984.

Hammermaster, G. (2010). Payment processing tips for small businesses. Journal of Accountancy, 210(2), 22.

Huber, W., Brady, M., Deng, Q., Wei, X., Zhang, M., Zhang, R., \& Zhang, X. (2017). Micro retail enterprises in China: Challenging the stereotype. Journal of US-China Public Administration, 14(2), 74-82.

Li, S. C. (2014). Research on simulation of credit risk of credit card based on multi-agent. Procedia Computer Science, 31, 517-522.

Liu, C., \& Huang, X. (2016). The rise of urban entrepreneurs in China: Capital endowments and entry dynamics. Growth and Change, 47(1), 32-52.

Liu, X. (2008). SME development in China: A poicy perspective on SME industrial clustering. In H. Lim (Ed.), SME in Asia and globalization (pp. 37-68). ERIA Research Project Report 2007-5.

Liu, Y. (2015). Consumer protection in mobile payments in China: A critical analysis of Alipay's service agreement. Computer Law \& Security Review, 31(5), 679-688.

Mckay, L. (2010). Generation Green: Why Gen Y and the Millennials are greener than you'll ever be. CRM Magazine, $14(4), 12$.

Pistrui, D., Huang, W., Oksoy, D., Jing, Z., \& Welsch, H. (2001). Entrepreneurship in China: Characteristics, attributes, and family forces shaping the emerging private sector. Family Business Review, 14(2), 141-152.

Russell, C. (2016). New youth: Understanding China's millennials. Retrieved from http://knowledge.ckgsb.edu.cn/2016/02/03/ demographics/new-youth-understanding-chinas-millennials/

Shi, H. P. (2007). Barriers to the implementation of cleaner production in Chinese SMEs: Government, industry and expert stakeholders' perspectives. Journal of Cleaner Production, 16(7), 842-852.

Statista. (n.d.). Number of smartphone users in China from 2013 to 2022 (in millions). Retrieved from https://www.statista.com/ statistics/467160/forecast-of-smartphone-users-in-china/

Tencent Technology. (2016). Penguin intelligence|WeChat report: 47 PPT read five major businesses. Retrieved from http://tech. qq.com/a/20160321/007049.htm\#p=1

The Economist. (2008). The limits of leapfrogging: The spread of new technologies often depends on the availability of older ones. Retrieved from http://www.economist.com/node/10650775

Wang, C. (2009). Little emperors: The future of China's consumer market. Young Consumers, 10(2), 95-97.

Worthington, S., Thompson, F. M., \& Stewart, D. B. (2011). Credit cards in a Chinese cultural context-The young, affluent Chinese as early adopters. Journal of Retailing and Consumer Services, 18(6), 534-541.

Wu, J., Liu, L., \& Huang, L. (2017). Consumer acceptance of mobile payment across time: Antecedents and moderating role of diffusion stages. Industrial Management \& Data Systems, 117(8), 1761-1776.

Xiao, E. (2017). How WeChat Pay became Alipay's biggest rival. Retrieved from https://www.techinasia.com/wechat-pay-vsalipay 